\title{
Inheritance, calquing, or independent innovation? Reconstructing morphological complexity in Amazonian numerals
}

\author{
Patience Epps \\ pattieepps@austin.utexas.edu
}

\begin{abstract}
The reconstruction of morphologically complex forms offers familiar problems. As illustrated by textbook examples like Bloomfield's seemingly reconstructable anachronism-Algonquian 'firewater' for 'whisky' - the existence of corresponding complex forms across related languages can alternatively be attributed to calquing or parallel independent innovation. This paper considers the problem of accounting for the history of complex forms in the context of the northwest Amazon, where lexical borrowing is actively resisted but calquing is rampant. Where complex forms are widely shared across related and unrelated languages, is there any hope of identifying their source, or establishing their relative age in particular groups of languages? I focus in particular on numeral terms, which reveal considerable complexity among northwest Amazonian languages. I evaluate the challenges encountered in gauging the time-depth and reconstructability of morphologically complex forms, and the criteria-comparative, typological, and geographical-that must be brought to bear in weighing more or less probable histories of complex forms.
\end{abstract}

\section{Keywords}

calquing; reconstruction; complex forms; contact; Amazon; Vaupés

\section{Introduction}

Morphologically complex forms present particular challenges in reconstructing the history of a language. A familiar illustration is Bloomfield's (1946)

* This work was funded by National Science Foundation grant HSD0902114, 'Dynamics of Hunter-Gatherer Language Change'. The investigation of Amazonian 'relational' numeral terms was carried out in collaboration with Cynthia Hansen, with assistance from Ana Paula Brandão, Kelsey Neely, Leslie Smith, Emily Buell, and Dhananjay Jagannathan. The author thanks the audience of the Symposium on Contact Between Genetically Related Languages (University of Texas at Austin, April 2012) for discussion and comments, and to Marianne Mithun and two reviewers for their suggestions for improving the paper. All remaining shortcomings are the author's own responsibility. 
'reconstruction' of a term for 'whisky' in Proto-Central Algonquian, *eškoteewaapoowi, literally 'fire-water'. The expected sound correspondences are present-there is no question that the components are cognate- but the word is an obvious anachronism. How did the corresponding 'whisky' terms emerge among the Central Algonquian languages?

As Hockett (1948: 127) observes, the existence of a common set of morphologically complex terms across related languages-like Algonquian 'whisky' - may be due to a variety of processes:

Each of the modern languages concerned has coined new terms for the new items of material culture, using identical (cognate) morphemes according to identical patterns of formation, in such a way that the phonemic correspondences between the whole words are perfect. But it might also be that the terms themselves date from [Proto-Algonquian] times, and that since the introduction of whisky and guns by Europeans the semantic shifts have been parallel in the various languages. Or, as European influence spread, the forms may have been invented by the speakers of one language and then borrowed by loan-translation into the other languages. ${ }^{1}$

While the challenges of teasing apart similarities due to contact, inheritance, parallel drift, and pure coincidence are encountered generally in reconstruction (see, for example, Sapir, 1921; Hock, 1991; Aikhenvald, 2007; inter alia), these problems are multiplied in the case of morphologically complex forms. The difficulty of choosing among the many possible explanations leads historical linguists to be broadly skeptical of our ability to reliably reconstruct complex forms at all. For example, Hockett (1948: 128)—in noting that our linguistic inferences about speakers' pasts are only as good as our reconstructions-observes that "the danger is less, though probably still considerable, if the forms compared are morphologically simple than if they are compounds." Similarly, Hock (1991: 576) stresses that reconstruction of morphologically complex forms has a low degree of confidence, and warns against "putting excessive faith in such merely possible reconstructions," as opposed to those that can be identified as probable.

Lexical compounds, like 'fire-water' above, are the most common source of questions in reconstructing language histories; however, I use here the more general term 'morphologically complex form' in recognition of the other kinds of word-formation processes (e.g. involving class terms or other derivational

${ }^{1}$ Likewise, Bloomfield (1946) observed for complex Algonquian terms like 'whisky' and 'gun' that "the meaning is modern, but the habit of formation is old." 
elements) that can present similar challenges. In fact, much of the puzzle lies in the idiomatic nature of such constructions, in that a metaphorical association is drawn between the literal meaning of the component word(s) such as 'fire'-and the meaning of the resulting expression. While the recurrence of such idiomatic associations across related languages is not limited to morphologically complex forms, it is far more prevalent among these than it is with simplex forms.

In light of the cautions observed by Hockett, Hock, and others, how should we evaluate the histories of morphologically complex forms, particularly among related languages? To what extent are morphologically complex forms susceptible to distinct processes of language change, in comparison to those that affect simplex forms? Are there principled ways to distinguish between calquing, parallel innovation, and inheritance? Where reconstruction is concerned, are all complex forms to be shunted equally into the 'merely possible' category, or are there ways to distinguish between forms for which reconstruction within a given language family is more or less probable? Similarly, where we can be certain that widespread calquing of complex forms has indeed taken place, can we identify its source-which may require demonstrating its relative age within a given group of languages?

This paper explores these questions through a series of examples from languages of the northwest Amazon, particularly the Vaupés region of eastern Colombia and northwest Brazil. These languages present a relevant test case for investigating questions of inheritance and contact: across the region, high linguistic diversity, non-contiguous distributions of language families, and relatively low levels of lexical borrowing give us tools for teasing apart inheritance and contact. At the same time, contact among some of these languages has been relatively intense, and has left its traces behind in shared grammatical structures and lexical calques.

After first providing an overview of Amazonian languages and the Vaupés region (section 2), the discussion considers several cases of morphologically complex lexical forms that are widely shared among Vaupés languages, and support the observation that lexical borrowing and calquing are profoundly different processes (section 3). The investigation focuses in particular on numeral terms, which exhibit a tendency toward morphological complexity in the region (section 4). Throughout the discussion and in the conclusions (section 5), I consider the criteria by which it may be possible to distinguish between more or less probable reconstructions of morphologically complex forms. Notably, I argue that these criteria must draw on both linguistic and extra-linguistic evidence. 


\section{The Amazonian context and the Vaupés region}

Languages of the Amazonian basin exhibit a high degree of linguistic diversity. The region is home to some 300 languages, which belong to over fifty different genetic groupings, including many isolates (Rodrigues, 2000). The few language families that are relatively spread out across the region-most notably Arawak, Carib, Tupi, and Macro-Jê-tend to non-contiguous distributions (see Dixon and Aikhenvald, 1999; Epps, 2009a; Aikhenvald, 2012a: 32).

Despite the wide diversity among Amazonian languages and peoples, linguistic, cultural, and historical evidence suggests that interaction has been frequent and often far-reaching, leading to shared features of cultural practice, discourse, and language (e.g. Neves, 2001; Beier et al., 2002). Certain regions have experienced particularly high levels of interethnic contact and (in some cases) pervasive multilingualism, as in the Vaupés, the Xingu, and the CaquetáPutumayo regions (e.g. Stenzel, 2005; Fausto et al., 2008; Seifart, 2011). Nevertheless, recent work suggests that interactions among native lowland languages have tended to yield relatively low levels of lexical borrowing, even in regions where relatively profound contact has taken place (e.g. Carlin, 2006; Bowern et al., 2011; Seifart, 2011; Seki, 2011; Epps, 2012).

This paper takes as its primary focus the languages of the Vaupés region, located on the border of eastern Colombia and northwest Brazil (see Figure 1). This region is home to languages belonging to four distinct families: Arawak (represented primarily by Tariana, with Baniwa and several other languages on the margins); East Tukanoan (a shallow grouping of over a dozen languages, including Tukano, Desano, Kotiria/Wanano, etc.); Nadahup (represented by Hup and Yuhup, with Dâw on the margins and Nadëb further to the east); and Kakua-Nukak (with Kakua inside the Vaupés and Nukak to the west). ${ }^{2}$ In addition, linguistic newcomers to the region are Nheengatú (also known as Lingua Geral, a Tupi-Guaraní language spread by Jesuit missionaries in the 16th-19th centuries), Portuguese, and Spanish.

Vaupés multilingualism is striking not only on a regional level, but on an individual level as well. For the majority of the region's ethnic and linguistic groups, adults are able to speak and/or understand multiple languages. In the case of the East Tukanoan and Tariana peoples - who are river-dwellers with a focus on farming and fishing - this multilingualism is fostered by the practice of linguistic exogamy, by which marriages are explicitly required to occur

\footnotetext{
${ }^{2}$ Nadahup and Kakua-Nukak have previously been assumed to form a single 'Makú' family; see discussion below.
} 


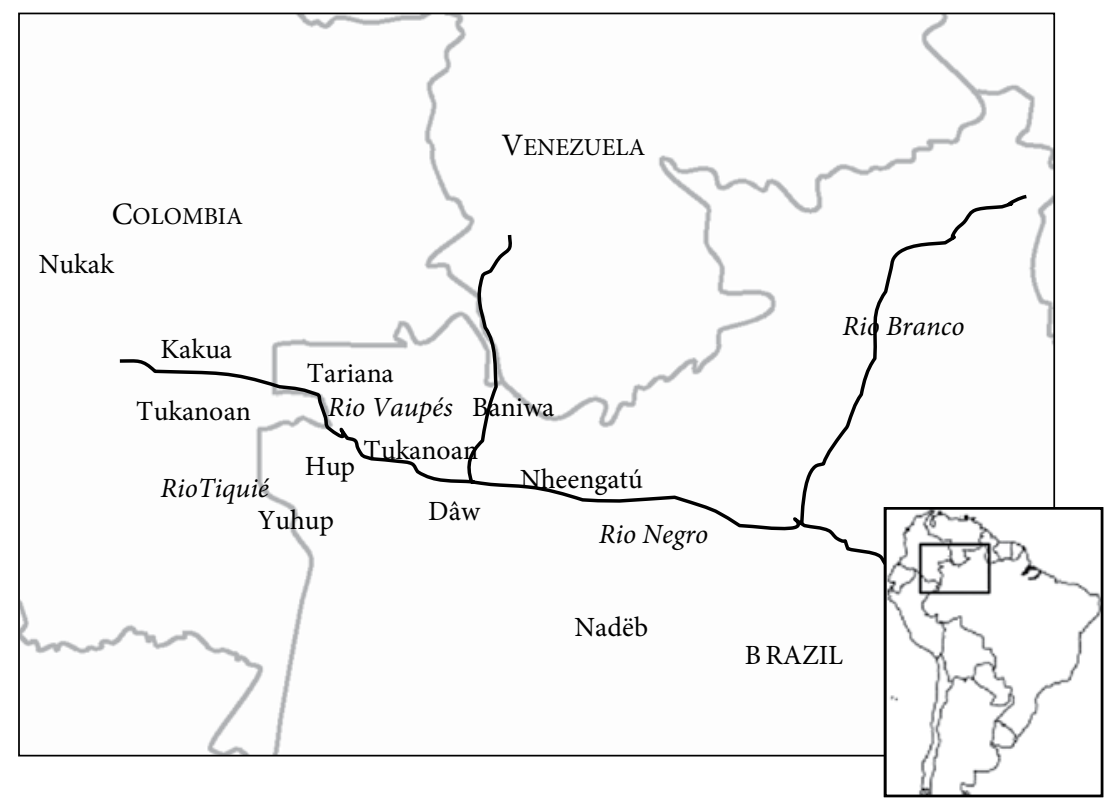

Figure 1. The Vaupés region.

across linguistic/ethnic lines. Thus River Indian communities are necessarily multilingual, since all the married women are representatives of other language groups. The Nadahup and Kakua peoples, on the other hand-who traditionally live in the interfluvial zones and rely heavily on hunting and gathering-do not practice linguistic exogamy. However, their long-term and semi-institutionalized socioeconomic interactions with the River Peoples have led to pervasive bilingualism among adults, mostly in Tukanoan languagesalthough this bilingualism is not reciprocated due to the social imbalance that pertains between the River and Forest Peoples of the region (for further discussion, see Epps and Stenzel, 2013).

Multilingualism in the Vaupés comes along with a strong cultural constraint to keep the languages distinct, and to avoid mixing. For the River Peoples, this constraint is explicitly associated with linguistic exogamy; for example, Jackson (1983: 170) records a Barasana speaker's rhetorical question, "If we were all Tukano speakers, where would we get our women?" Accidental slips resulting in code-switches or nonce borrowings are subject to social disapproval and active ridicule (see also Aikhenvald, 2002a, 2003; Stenzel 2005). Similar constraints against language mixing are in place among the Forest Peoples; 
although these groups do not participate in the exogamy system, their attitudes likely derive in part from their participation in the wider Vaupés regional 'system'. Linguistic exogamy thus offers an obvious cultural explanation for the avoidance of language-mixing in the Vaupés; however, this exogamy may itself represent a relatively extreme instantiation of more widespread regional trends, which favor an ideal of linguistic purity and stress an association between linguistic and social identity (see references above).

Vaupés multilingualism, coupled with conscious efforts to avoid mixing languages, has had particular linguistic outcomes. In general, intrasentential code-switching is not tolerated, and lexical borrowings are very few across the region's languages - especially in light of the intensity of contact. Contrary to cross-linguistically typical patterns of borrowing, lexical loans that do exist exhibit a high percentage of bound verb roots that appear in complex compound constructions. This tendency is probably motivated by the fact that bound forms are more easily smuggled in without notice, and thus escape censorship (see Epps, 2007: 285; Aikhenvald, 2012b).

In contrast to the limited effects of contact on Vaupés lexicons, multilingualism has fostered extensive diffusion of grammatical structures and categories. As with the borrowed verb roots, this diffusion has doubtless been facilitated by a lower degree of awareness of such structures on the part of speakers. The effects of contact on Vaupés grammars are varied and pervasive, and include the development and/or restructuring of nominal classification systems, with recurrent patterns prioritizing shape and gender in classifying inanimates and animates; development of common strategies in verb serialization; the elaboration of multiple, closely comparable categories of evidentiality; etc. (see, for example, Gomez-Imbert, 1996; Aikhenvald, 2002a; Epps, 2007, 2008a; Bolaños, 2010; Stenzel, 2013). In general, East Tukanoan languages appear to have been the primary driver of contact-related change in other languages of the region, most notably Tariana (see Aikhenvald, 2002a, etc.) and Hup (see Epps, 2007, 2008a). While Tukanoan languages appear to have themselves experienced significantly fewer effects from their neighbors (although exceptions exist, such as the effects of Baniwa on Cubeo nominal classification, as described by Gomez-Imbert, 1996), the extent of familyinternal borrowing is difficult to evaluate because the languages are so closely related (see Stenzel and Gomez-Imbert, 2009; Chacon, forthcoming).

The restructuring of grammatical systems among the Vaupés languages has given rise to a relatively consistent typological profile across the region, involving prosodic tone and nasalization, nominative-accusative alignment, verb-final constituent order, a strong preference for suffixing, and similar patterns of case marking and tense-aspect-mode specification, as well as the 
categories listed above. For some languages, externally motivated change has led to profound grammatical differences between them and their sister languages. This is particularly evident in the Nadahup family; Hup, Yuhup, and to some extent Dâw (within and on the periphery of the Vaupés) are in striking contrast to their sister Nadëb, which is toneless, ergative-absolutive, predominantly prefixing, and exhibits only minimal evidential distinctions and nominal classification.

On the other hand, the fact that vocabulary in the Vaupés is relatively resistant to replacement by loanwords makes genetic relationship reasonably easy to establish. Nevertheless, prior assumptions of a genetic relationship between Kakua-Nukak and Nadahup, which were lumped together to form the almost certainly spurious 'Makú' family (see, e.g. Campbell, 1997; Martins and Martins, 1999), illustrate the danger of making uncritical assessments of genetic relationship in situations of profound language contact. Proposals for a relationship referred to a small number of similar lexical forms shared between Hup and Kakua - most of which are almost certainly loanwords; proposals were undoubtedly also influenced by the many grammatical and phonological similarities among these languages (most of which are common to the Vaupés languages generally), and by the shared cultural category of 'Forest Indian' (Bolaños and Epps, 2009).

\section{Morphologically complex forms in Vaupés languages}

\subsection{Calquing in the Vaupés}

A notable feature of the common Vaupés linguistic profile is the many close parallels among morphologically complex forms in the region's languages. These shared lexical structures point to extensive calquing, which appears to have proceeded unchecked despite the general ban on the borrowing of lexical and morphological forms. As calques, these forms are distinguished by the close translation of their component parts from language to language, such that the actual morphological material remains native to the language in question, but a shared meaning arises via language contact. As noted above, a distinguishing feature of these calques tends to be their idiomatic quality, involving a metaphorically motivated semantic shift. A comparable process can thus affect morphologically simplex as well as complex forms, but complex forms are far more prone to undergo it. Examples of idiomatically motivated semantic shift in simplex forms in Vaupés languages include the use of a single term for 'deer' and 'manioc tripod' and for 'sun' and 'moon' 
(e.g. in Hup, Epps, 2007: 285; and Tariana, Aikhenvald, 1996: 98), and can also be seen in certain ethnonyms and place names (see 3 below).

Examples of parallel complex terms in Vaupés languages are prevalent in several semantic domains. One of these is ritual and material culture, as illustrated in (1). Many of these terms pertain to non-native material objects and other entities (e.g. 'wristwatch' and 'hospital') and owe their complexity in part to their recent innovation; others (e.g. 'Bone-Son', a culture figure) are probably older. Note that the closeness of the calquing varies; for example, both Tukano and Tariana include a 'round object' classifier in their term for 'clock, watch', but the Tariana variant also involves a relativizing prefix. Similarly, the culture figure is termed 'Bone-Son' in both Hup and Tukano, but the Tariana variant (and the Baniwa as well) is 'One on the Bone' (see Hill 2009 for discussion of this figure and its name). Thus it is their idiomatic nature, rather than their structure per se, that gives the clearest indication that language contact has played a role in their formation.

(1) Ritual and material culture terms (Ramirez, 1997; Aikhenvald, 1996: 98, 2002a: 229, 2003: 13; Epps, fieldnotes)

\begin{tabular}{|c|c|c|c|}
\hline Tukano & Tariana & Hup & \\
\hline $\begin{array}{l}\text { imiko keo-ga } \\
\text { (day measure- } \\
\text { CL:ROUND) }\end{array}$ & $\begin{array}{l}\text { ehkwapi ka-wa-ka-da } \\
\text { (day REL-mark-TH- } \\
\text { CL:ROUND) }\end{array}$ & $\begin{array}{l}\text { wag tễ kéy } \\
\text { (day measure.NMLZ) }\end{array}$ & $\begin{array}{l}\text { 'day measure }(\mathrm{r}) \text { ' = } \\
\text { 'clock; watch' }\end{array}$ \\
\hline $\begin{array}{l}\text { thko-wii } \\
\text { (medicine-house) }\end{array}$ & $\begin{array}{l}\text { di-tape-dapana } \\
\text { (3sg.nf-medicine- } \\
\text { CL:HOUSE) }\end{array}$ & $\begin{array}{l}y \check{\check{\partial} h} \text { moy } \\
\text { (medicine house) }\end{array}$ & $\begin{array}{l}\text { 'medicine-house' = } \\
\text { 'hospital' }\end{array}$ \\
\hline $\begin{array}{l}\hat{o} \hat{a}-k \dot{t} \\
\text { (bone-son) }\end{array}$ & $\begin{array}{l}\text { yapi-riku-ri } \\
\text { (bone-LOC-REL) }\end{array}$ & $\begin{array}{l}\text { g'ǎg têh } \\
\text { (bone son) }\end{array}$ & $\begin{array}{l}\text { deity/culture figure } \\
=\text { 'Bone Son' or } \\
\text { 'One on the Bone' }\end{array}$ \\
\hline
\end{tabular}

Flora-fauna terms, primarily referring to species or varietal levels, also tend to involve compounding and make idiomatic reference to other entities, as seen in (2). A comparative study of Hup and Tukano indicates that roughly $80 \%$ of such binomial flora-fauna terms are direct translations between the two languages. ${ }^{3}$

${ }^{3}$ Unfortunately, the available materials on other languages of the area do not give enough detail about species/varietal-level distinctions to determine how widely these patterns pertain. However, Aikhenvald's (2010) Tariana dictionary includes a few terms that parallel those found in Hup and Tukano; e.g. wesiri deri 'inajá banana' (inajá is a palm species, Attelea maripa). 
(2) Flora-fauna terms (Epps, fieldnotes; Ramirez, 1997)

\begin{tabular}{|c|c|c|}
\hline \multirow{2}{*}{$\frac{\text { Tukano }}{\text { yamâ ís } \hat{e}}$} & \multicolumn{2}{|l|}{ Hup } \\
\hline & 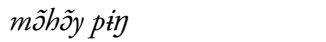 & 'deer grape' \\
\hline (deer Amazon.tree.grape) & (deer Amazon.tree.grape) & \\
\hline akó dasê & děh cokw’át & 'water toucan' \\
\hline (water toucan) & (water toucan) & \\
\hline mahâ mere & yăk min & 'macaw ingá' \\
\hline (macaw ingá) & (macaw ingá) & \\
\hline$i k \hat{\imath} o h o ̂$ & g’ab pihbît & 'inajá banana' \\
\hline (inajá banana) & (inajá banana) & \\
\hline
\end{tabular}

Place names and ethonyms also exhibit extensive parallels throughout the region, including their variants in Nheengatú (which have also become the standard forms in the regional Portuguese, as well as in the wider linguistic and ethnographic literature):

(3) Place names and ethnonyms (Aikhenvald, 1996, 2002b; Ramirez, 1997; Epps, fieldnotes; Floyd, 2013)

\begin{tabular}{|c|c|c|c|c|}
\hline $\begin{array}{l}\text { Nheengatú / } \\
\text { Portuguese }\end{array}$ & Tukano & Tariana & Hup & \\
\hline $\begin{array}{l}\text { Tukano } \\
\text { (toucan) }\end{array}$ & $\begin{array}{l}\text { Dase-á } \\
\text { (toucan-ANIM.PL) }\end{array}$ & $\begin{array}{l}\text { Yáse-ne } \\
\text { (toucan-ANIM.PL) }\end{array}$ & $\begin{array}{l}\text { Cokw'at-d'ah } \\
\text { (toucan- } \\
\text { ANIM.PL) }\end{array}$ & 'Toucan People' \\
\hline $\begin{array}{l}\text { Pira-Tapuyo } \\
\text { (fish-people) }\end{array}$ & $\begin{array}{l}\text { Wầ-kĩht } \\
\text { (fish-people) }\end{array}$ & $\begin{array}{l}\text { Kuphé-mene } \\
\text { (fish-ANIM.PL) }\end{array}$ & $\begin{array}{l}\text { Hõp-d'ah } \\
\text { (fish-ANIM.PL) }\end{array}$ & 'Fish People' \\
\hline $\begin{array}{l}\text { Yawarete } \\
\text { (jaguar) }\end{array}$ & $\begin{array}{l}\text { Yâे-poêwa } \\
\text { (jaguar-rapids) }\end{array}$ & $\begin{array}{l}\text { Yawhipani } \\
\text { (Yawi-hipani) } \\
\text { (jaguar-rapids) }\end{array}$ & $\begin{array}{l}\text { Ya?am-húh } \\
\text { (jaguar-rapids) }\end{array}$ & 'Jaguar Rapids' \\
\hline
\end{tabular}

Similar parallels can be seen in many other constructions in the Vaupés languages, spanning lexicon, grammar, and discourse. For example, the regional equivalent of 'good morning' is the following:

(4) Morning greeting:

\begin{tabular}{|c|c|c|c|c|}
\hline Tukano: & $w a a^{\prime} k a-t i$ & $m \ddot{t} \hat{t}$ & & (Ramirez, 1997: 210) \\
\hline & be.awake-INTERROGATIVE & you & & \\
\hline Tariana: & kawhi-tha & & phia & (Aikhenvald, 2002a: 138) \\
\hline Hup: & $\begin{array}{l}\text { be.awake-VISUAL.PAST.INTI } \\
\text { cəwə?-əy }\end{array}$ & $\begin{array}{l}\text { RROGATIVE } \\
\text { Pam }\end{array}$ & you & (Epps, fieldnotes) \\
\hline & $\begin{array}{l}\text { be.awake-DYNAMIC } \\
\text { 'Are you awake?' }\end{array}$ & you & & \\
\hline
\end{tabular}


There is no doubt that most of the structures discussed here have involved calquing among the Vaupés languages. This process tends to be easily identified where the languages belong to different families (compare Campbell et al.'s 1986 discussion of the 'historicist' approach to establishing that language contact has occurred). For example, Aikhenvald (2002a: 229) argues for calquing in Tariana based on the absence of comparable forms in Baniwa, Tariana’s sister language located just outside the Vaupés; similarly, some Hup examples have no attested parallels in Dâw or Nadëb. ${ }^{4}$ A Tukanoan source for many of these lexical constructions is consistent with the general direction of diffusion in the region (see section 2 above); on the other hand, the presence in Baniwa of a comparable culture-figure name (ñapirikuli 'One on the Bone') suggests that at least this term may have originated in Arawak (though it probably entered Hup via Tukano; see Epps, 2009b).

Particularly in cases where contact may not have been so pervasive as among the Vaupés languages, however, we must also consider the possibility of independent innovation - where the processes of word formation have followed parallel paths in more than one language, but without direct copying from one language to another. Of course, 'independence' of innovation is something of a relative notion, in that a particular change may itself be facilitated by shared structural patterns or by cultural norms and preferences that favor certain conceptual associations. Determining the likelihood of contact as a direct motivation for the shared feature essentially comes down to gauging the naturalness of the change, as is true for many other aspects of language evaluated in historical work (sounds, morphological patterns, etc.). For the complex lexical constructions considered here, the question of naturalness relates primarily to the extent to which the new meaning is idiomatic and thus more arbitrary, as opposed to being simply the sum of its parts, as well as to the particular components involved and the order of their occurrence.

Where a parallel complex form is represented among related languages, as in the case of East Tukanoan, inheritance is also a possible explanation for its presence. Yet where these languages are themselves in contact—as is true for many of the East Tukanoan languages, whose speakers regularly intermarryit may be close to impossible to distinguish inheritance from family-internal calquing. Similarly, where the meaning and form of the complex term are relatively natural, it is difficult to distinguish contact-driven from parallel

\footnotetext{
${ }^{4}$ For example, Hup, Yuhup, and Dâw - but not Nadëb - use a single word for both 'sun' and 'moon', as do other Vaupés languages, and Hup and Yuhup (but not Dâw or Nadëb) use 'one hand' for 'five'. Unfortunately, however, lexical data from Dâw and Nadëb are scarce.
} 
independent innovation, especially when this coincidental innovation has involved cognate components and inherited concatenation processes. Accordingly, among closely related sister languages, especially those like East Tukanoan that have remained in contact, we may only be able to establish a complex form's history with any confidence in the case of certain calques, when these exhibit a clearly recent meaning and a relatively arbitrary collocation-such as 'day-measure' for 'clock/watch'-that allow us to rule out inheritance and parallel independent innovation with some degree of certainty.

\subsection{Calquing and lexical borrowing as distinct processes}

In the Vaupés languages, as we have seen, morphologically complex forms are highly susceptible to calquing even where lexical borrowing is tightly constrained. This distinction indicates that, for speakers, the full transfer of form and meaning evident in loanwords involves different processes than those responsible for the transfer of meaning and some aspects of formal structure that we see in calquing.

What are the reasons behind this difference? Part of the answer undoubtedly has to do with the degree to which speakers are aware of different components of their language. As Silverstein (1981) observes, lexical forms (as linguistic elements that are relatively referential, segmentable, and presupposing) are more accessible to speaker awareness than are grammatical structures and categories. Conscious constraints against language mixing will therefore affect the lexicon far more than they affect the grammar-as we see in the Vaupés, where lexical borrowing and grammatical diffusion have proceeded at very different rates. Presumably, the fact that calquing does not involve the direct transfer of (phonological) form allows it, like grammatical diffusion, to operate largely below the level of speaker awareness.

However, the 'limits' of speaker awareness are clearly not represented by a discrete boundary, but rather conform to something more like a sliding scale by which particular linguistic features will be more or less susceptible to conscious manipulation, and where variation will occur both within and across individuals. In the Vaupés, verb roots are apparently less salient to speakers than are nouns (probably because, in Silverstein's terms, they are somewhat less segmentable and less referential), and are thus more susceptible to borrowing - though still generally resistant. Similarly, speakers' awareness of lexical calques as associated with another language is likely below that of loanwords, which involve more foreign material, but higher than that of grammatical structures, which are more function-oriented. We note, for example, that some Hup speakers identify particular calques as deriving from 
Tukano, much as they do for occasional semi-established loanwords, but rarely if ever for grammatical constructions. ${ }^{5}$

The susceptibility of morphologically complex forms to contact-driven transfer is likely not only a function of speaker awareness, but also comes from the relatively active role that morphologically complex forms play in organizing systems of knowledge through discourse. In contrast to simplex lexical items, complex forms often contain extra information, such as explicit indicators of category membership, that have discursive relevance. A particularly interesting example is found in the role that flora and fauna terms-and their taxonomic organization-play in incantations across various languages of the Vaupés region and beyond (see Hill, 1988 for Baniwa-Kurripako; Buchillet, 1992 for Desano). Typically, incantations in the region invoke exhaustive catalogues of plants or animals that are seen to be associated in some way with a particular malady. A full catalog-down to the varietal level—is important to the success of the incantation. To illustrate, the following segment (5) comes from a Hup incantation to dispel the 'spines' or 'splinters' by which a malignant entity sends illness into a victim. In part (5b), the incantation lists different kinds of spiny trees that grow along the rivers, varieties of uacu (Monopteryx uacu), pupunha (Bactris gasipaes), and abiu (Lucuma sp.). Part (5c) catalogs the different kinds of plants used to make poison for darts (actually or metaphorically), including varieties of paricá, a tree from which shamans derive a hallucinogen.

(5) Hup incantation for dispelling illness-bearing 'spines'

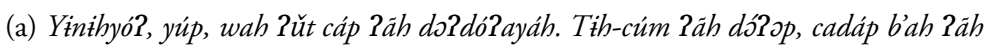
dóPop, n'ik'an hõpd'ah nŭhan?ǔy, hõpd'ah nŭhan?ǔy. Päh do?téh, hõpd'oh nŭhan?ǔy...

${ }^{5}$ For example, a Hup consultant identified the varietal flora term 'woolly-monkey ingá as a Tukano calque, and noted the alternative 'true' Hup form as 'curly inga'. However, as a reviewer points out, cultural conventions relating to 'descriptive' terms could provide a distinct motivation for calquing; the extent to which loanwords, lexical calques, and grammatical constructions actually correspond to a hierarchy of salience awaits further exploration.

${ }^{6}$ The binomial plant names in this text are repeated here with full glossing:

děh yăh, děh yáh b’ah, děh wahnáw b’ah, děh c’țw b’ah... water uacu water uacu splinter water abiu splinter water pupunha splinter 'Water-uacu, water-uacu splinter, water-abiu splinter, water-pupunha splinter...'

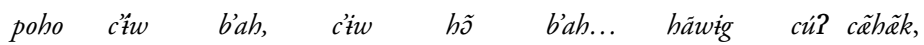
yellow pupunha splinter pupunha ripe/red splinter heart grab paricá 'yellow pupunha splinter, ripe/red pupunha splinter...' 'heart-grab paricá,

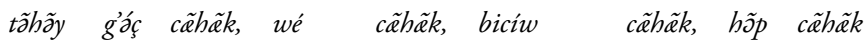
snake bite paricá tree.sp. paricá bisiw.spirit paricá fish paricá 'snake-bite paricá, we-tree paricá, bisiw paricá, fish paricá...' 
With this, I list the patoá-spines (magical vehicles of illness). First I list, the sadap splinters I list, those belonging to those fish over there (toward the river's mouth). I list those (spines/splinters) belonging to the fish...

(b) Děb yáh, děb yáh b'ah, děb wahnáw b'ah, děb c'áw b’ah, hõp hup-Tîh nŭh, hõp hup-?îh nüh, tinťh, tỉh do?nip, yúp hõp hup-?áy tỉ do?nip.

Water-uacu, water-uacu splinter, water-abiu splinter, water-pupunha splinter, the fish-man's, fish-man's, his yellow pupunha splinter, ripe/red pupunha splinter, she takes it, that fish-woman takes it (to make spines).

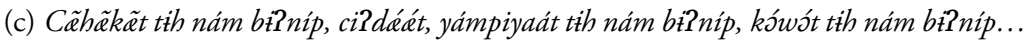

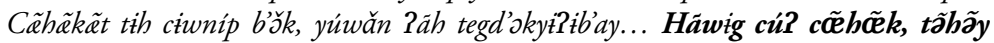

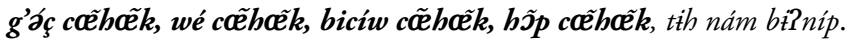

They make poison from paricá, from sidé grass, from yámpia plant, they make poison from chili pepper (to put on the spine/splinter)... Their paricá-cooking pot, I put out its fire... Heart-grab paricá, snake-bite paricá, we-tree paricá, bisiw paricá, fish paricá, (with these) they poison.

Interaction among Vaupés peoples is realized through discourse; incantations, songs, stories, conversational norms, and other discourse forms are shared continuously from one group to the next. At the same time, complex lexical forms that play a role in organizing this discourse and facilitating its regional relevance-like flora-fauna binomials in incantations, parallel place names and ethnonyms, and so forth-are replicated through calquing. Thus speakers can participate fluidly within regional systems of knowledge and verbal expression, while still maintaining linguistic distinctions.

The Vaupés case offers clear evidence that the processes of contact-driven transfer available to morphologically complex forms are distinct from those involved in the direct borrowing of lexical forms, i.e. loanwords. Their transfer involves different mechanisms, and has different kinds of relevance for speakers. This distinction between calquing and lexical borrowing has implications for linguistic reconstruction: Because low levels of lexical borrowing do not necessarily correspond to low levels of lexical calquing, we cannot rely on the histories of simplex forms to inform our decisions about those of complex forms.

\section{Complex forms and reconstructability: Vaupés numeral terms}

In regions like the Vaupés where contact is intense, we may ask whether it is ever possible to reconstruct morphologically complex forms. Even where the relative arbitrariness of collocations allows us to rule out independent 
innovation, is there any hope of distinguishing inheritance from calquing when languages are related? In this section, I consider the criteria that may allow us to sort out the histories of complex forms. Morphological complexity in numeral terms provides an illustrative case study.

\subsection{Terms for 'two' and 'three' in Nadahup languages}

It is not unusual among Amazonian languages for numeral systems to be restricted-in many cases lacking terms above 3 or 5-and morphological complexity (including historical complexity, which may be obscured over time) of low-level numeral terms is relatively common throughout the region (Epps et al., 2012; Epps and Hansen, in prep.). In and around the Vaupés region, the Nadahup languages in particular exemplify these characteristics. The existence of morphologically complex and/or etymologically analyzable terms for even the lowest Nadahup numerals contrasts with the morphologically simplex terms for 1-3 found in Tukanoan and Arawak languages, and suggests relatively recent layers of numeral innovation. As detailed in Epps (2006), Nadëb (the most distant sister in the family) has terms only for 1-3, of which at least 'two' is reportedly imprecise; Dâw (which groups with Hup/ Yuhup) has terms for 1-3 plus terms relating to 'even' vs. 'odd' values that can be paired with gestures for 4-10; and Hup and Yuhup (the two most closely related sisters, both located within the Vaupés) have conventionalized terms for 1-5, with a further base-5 strategy (but without fully routinized terms) for numerals up to $20 .^{7}$

The Nadahup terms for 'two' and 'three' exhibit close parallels across the family, as described in detail in Epps (2006). ${ }^{8}$ As can be seen in (6), the Hup

7 The Nadahup family tree is represented as:

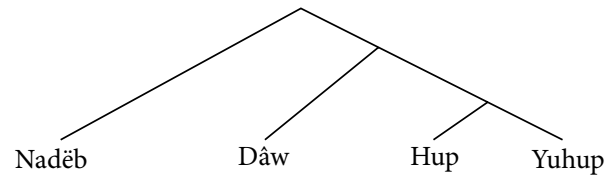

${ }^{8}$ In addition, the terms for 'one' in Nadëb, Yuhup, and Hup all appear to be related to demonstratives, but not to the same ones. It is likely that a demonstrative-numeral association goes back to Proto-Nadahup, but since the opposite trajectory (numeral 'one' > demonstrative/ article) is cross-linguistically common, the source of these 'one' terms is not easily established. (Sources of data for Nadahup languages are the following - Hup: Epps, 2006, 2008b: 310; Nadëb: Weir, 1984: 103-104; Dâw: V. Martins, 1994: 158; S. Martins, 2004: 391; Yuhup: Ospina, 2002: 455.) 
term for 'two' is morphologically complex (transparently so, in one variant), and both the Hup and Dâw terms are related to the respective words for 'eye' in those languages, although these are not in fact cognate between Hup and Dâw:

(6) Terms for 'two' in Nadahup languages

\begin{tabular}{|c|c|c|}
\hline Language & 'Two' & Etymology \\
\hline Nadëb & powsp '2, 3, a few' & ? \\
\hline Dâw & $t \breve{t}^{b} m$ & tib 'eye' \\
\hline \multirow[t]{3}{*}{ Hup } & ka?ăp & \\
\hline & ko?áp & \\
\hline & kawǎg-?ap & 'eye-quantity' \\
\hline Yuhup & băp & $?$ \\
\hline
\end{tabular}

As illustrated in (7), the terms for 'three' all derive from the complex form 'rubber-tree seed quantity'. The seed of the rubber tree (Hevea sp.) is distinctively three-lobed and is culturally salient in the region (being associated with an edible fruit, and also made into a favorite children's toy).

(7) Terms for 'three' in Nadahup languages

\begin{tabular}{lll}
\hline Language & 'Three' & Etymology \\
\hline Nadëb & tamawób & $\begin{array}{l}(t a-3 \mathrm{sg})+\text { 'rubber tree seed (quantity)' } \\
(?)^{9}\end{array}$ \\
Dâw & $\begin{array}{l}\text { mutuwap } \\
\text { mutwáp }\end{array}$ & 'rubber tree seed quantity' \\
Hup & móda?ap & 'rubber.tree-seed-quantity' \\
mót-wig-Pap & 'rubber.tree.seed-quantity' \\
\hline
\end{tabular}

These Nadahup numeral terms are conventionalized, and their morphological complexity is not necessarily fully transparent today. However, their forms do suggest that the metaphorical association between the numeral value and the item associated with it has been maintained over time. In Hup, most notably, morphologically transparent variants of the terms for 'two' and 'three' are

9 The probable cognacy between Nadëb tamawsb and the other Nadahup 'three' forms was not considered in Epps (2006). 
attested alongside phonologically reduced forms. In my experience with Hup speakers along the Rio Tiquié, the expanded forms are not in general use, but at least some speakers are aware of them.

The possibility that speakers may maintain an association between an abstract concept and a concrete referent over time has implications for determining linguistic history: It implies that we may be able to trace the time-depth of a particular meaning, even where the form has changed. A comparable example may be seen in terms for colors, which like numerals represent an abstraction from the concrete objects that are inherently associated with those properties. Especially for cultures where color reference carries a low functional load, color terms may come about via a gradual delinking and generalization of the abstract notion of color from specific objects-but this may be a slow process (Lyons, 1999; Kay and Maffi, 1999; Levinson, 2001). In the Papuan language Yélî Dnye, for example, the two dialectal variants of terms for 'red' correspond to the two different words for a species of red parrot that exist in these dialects; as Levinson points out, the co-existence of these terms suggests "that the reference to the bird is still salient, that these are partially live rather than fully dead metaphors" (Levinson, 2001: 18). We may compare this to the existence of two distinct forms for 'two' in Hup and Dâw, both of which mean 'eye', but involve non-cognate forms.

Determining the history of the complex numeral forms 'two' and 'three' in the Nadahup family requires us to weigh the relative probability of different historical scenarios. The associated meanings ('eye quantity' and 'rubber tree seed quantity') are not widely attested in numeral terms elsewhere in Amazonia or the rest of the world, suggesting that parallel independent innovation is unlikely; this is especially true for 'three', which furthermore (unlike 'two') is attested across all four members of the family. Generalized calquing is also unlikely, because comparable forms are unattested in other local languages in the region. Family-internal calquing could only have predated the dispersal of Nadahup languages, which are currently geographically separated; while Hup and Yuhup do maintain occasional contact, and there are linguistic indications that Dâw and Nadëb may have had some contact in the past (see Epps, forthcoming), there is no evidence that Dâw or Nadëb have come into contact with Hup and Yuhup since their dispersal. Thus, while we cannot rule out the possibility of early family-internal calquing or the independent innovation of 'two' in Hup and Dâw, inheritance appears to be a highly probable explanation for the shared existence of 'three' in at least some of these languages, and a somewhat probable explanation for that of 'two'although in the case of 'two' inheritance would have been limited to meaning 
and metaphorical association, rather than to form (see Epps, 2006 for further discussion). ${ }^{10}$

In sum, our reconstructions of morphologically complex 'two' and 'three' terms for Nadahup languages are arguably of more 'probable' than 'possible' status, particularly in the case of 'three'. To achieve 'probable' status, however, we must draw not only on comparative evidence (attestations across the family), but also typological information (the scarcity of comparable terms in other languages), and geographical evidence (the non-contiguous distribution of the Nadahup languages).

However, the example of numeral terms also highlights an additional difficulty in distinguishing between inheritance, calquing, and independent innovation: Perhaps especially for morphologically complex terms, associations between literal and more figurative or abstract meanings may retain their salience over time, even as form is replaced. Thus we may be able to argue for reconstruction even in the absence of cognate forms, even though this normally would be taken as evidence against inheritance. Conversely, not even the lack of cognacy in form may constitute definitive evidence for calquing or independent innovation among parallel complex forms in related languages.

\subsection{Terms for 4 in the Vaupés and beyond}

Morphological complexity in Vaupés numeral terms goes well beyond Nadahup 'two' and 'three'. In most of the region's languages, terms for 'four' are based transparently on the respective words meaning 'companion'. Terms for 'five' are also complex, deriving from 'one hand', and where additional terms exist they involve the addition of fingers and/or feet/toes (see Epps et al., 2012). Comparative evidence indicates that 'five' terms in Nadahup languages and Tariana are indeed calqued from Tukanoan (Aikhenvald, 2002a: 108; Epps, 2006), but the frequency of 'hand' as a source for 'five' throughout the world's languages makes independent innovation a likely alternative explanation for their wider distribution.

We focus here on the 'relational' (i.e. 'companion'-based) terms for 'four', which-in contrast to 'hand'-based terms for 'five'-are virtually unattested outside the Amazon basin, and thus typologically unusual (see Epps et al.,

${ }^{10}$ Of course, our evidence for reconstructing 'two' goes only as far as Proto-Dâw-Hup/ Yuhup, not Proto-Nadahup. Similarly, the possibility of contact between Dâw and Nadëb suggests that 'three' could easily have been calqued between these two languages, and thus only inherited in the Dâw-Hup/Yuhup branch as well. 
2012; Epps and Hansen, in prep.). Their cross-linguistic rarity is a strong argument against independent innovation, whereas calquing is in many instances an obvious explanation for their existence. Inheritance, on the other hand, is far more difficult to prove, but would allow us to identify a likely origin point for their subsequent diffusion.

In the Vaupés, the presence of a relational 'four' term (and, in a few cases, comparable variants for other values, probably created via back-formation) in Nadahup and Tariana almost certainly derives from contact with Tukanoan languages, in which such forms are widely attested (as discussed below). As noted by Aikhenvald (2002a: 108), Tariana kephunipe (ka-iphu-nipe [RELaccompany-NMLZ] 'the one who has a companion, 4') is calqued from Tukano, as evidenced by its absence in Tariana's sister Baniwa (which instead has ri$k w a-d a-k a$ [3SGNF-be.enough-CL:ROUND-DECL] 'it is enough, 4'). Similarly, Nadahup languages exhibit the relational terms listed in (8), but the absence of a comparable term (or in fact any 'four' term) in Nadëb, as well as the intensive contact known to have taken place between Tukanoan and Nadahup, are evidence that this too is a calque; however, it is unclear whether the calquing took place independently in each Nadahup language or in a common ancestor of Dâw and/or Hup and Yuhup (see Epps, 2006).

(8) Relational numeral terms in Nadahup ${ }^{11}$

Hup: $\quad$ (bi-)bab'-ni $\left[(\text { FACT-)accompany OR (FACT-)sibling-exist }]^{12}\right.$ 'sibling exists; accompanied, 4'

Upriver Hup dialect: $\quad b a b$ '-pã [sibling-NEG] 'no sibling, 3'

Yuhup: bábm- dí-wăp [companion-be-quantity OR accompany-quantity] 'sibling-exist quantity; accompany quantity, 4 '

Dâw: $\quad$ m'र्E mám' [one brother] 'one brother exists; 4,6,8,10'

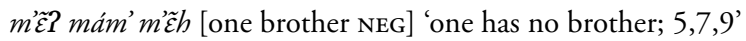

The history of relational 'four' in Tukanoan languages is more difficult to establish. The term is widely distributed within the family, providing additional support for a Tukanoan source in Tariana and Nadahup. Figure 2 shows all Tukanoan languages for which I have identified a term for 'four' in the available documentation, according to the subgrouping established by Chacon (forthcoming). Bolded language names indicate the presence of a relational

${ }^{11}$ Particularly in the case of even-odd variants like those seen in Dâw, these numeral terms may be paired with gestures and often function more like a tally system than designates of exact quantities (see Epps, 2006; Epps and Hansen, in prep.).

12 Both interpretations of the Hup form are possible. 


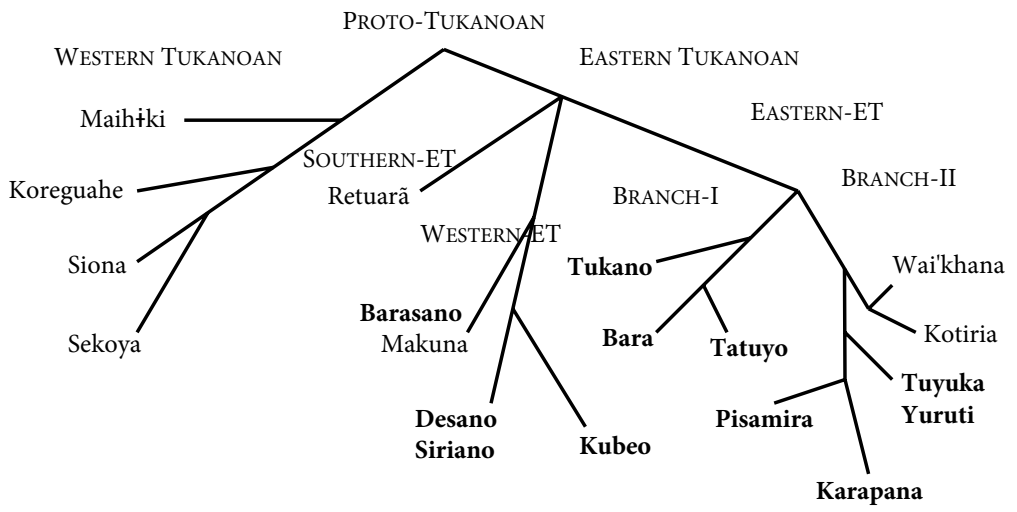

Figure 2. Relational 4 in Tukanoan languages (classification Chacon, forthcoming).

term (see 9 and 10 below), while plain font indicates that the language's term for 'four' (or 'three', 'five', etc.) is not known to be relational.

As Fig. 2 illustrates, relational numeral terms are altogether absent in West Tukanoan languages. Among the East Tukanoan languages, on the other hand, relational terms are widespread in the Western (9) and Eastern (10) branches of this subgroup. Attestations of 'four' attested in the Southern branch are limited to Retuarã bo'ta-raka- (etymology unclear). ${ }^{13}$

(9) East Tukanoan, Western branch:

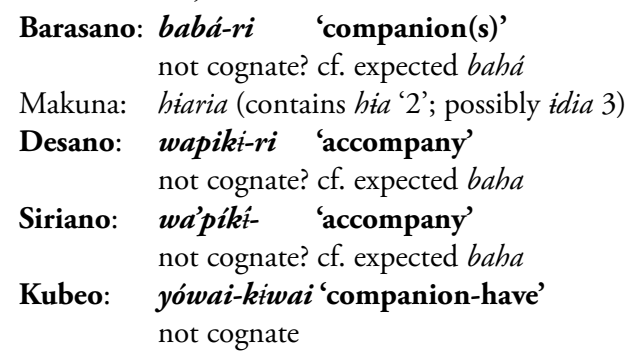

(10) East Tukanoan, Eastern branch (subgroups I and II):

$\begin{array}{lll}\text { Tukano: } & \text { ba'pá-ritise } & \text { 'having companion(s)' } \\ \text { I Bará: } & \text { bapá-ri } & \text { 'companion(s)' } \\ \text { Tatuyo: } & \text { bapa-ri } & \text { 'companion(s)' }\end{array}$

${ }^{13}$ Data on Tukanoan numerals come from the following sources: Huber and Reed, 1992; Strom, 1992; Ramirez, 1997; Miller, 1999: 46-47; Morse and Maxwell, 1999; Stenzel, 2004: 185-191 and p.c.; Gomez-Imbert, 2009; Thiago Chacon, p.c.). 


\begin{tabular}{|c|c|c|c|}
\hline \multirow{6}{*}{ II } & Karapana: & bapa-ri & 'companion(s)' \\
\hline & Pisamira: & bapú-ra & 'companion(s)' \\
\hline & Tuyuka: & ba’pá-ri & 'companion(s)' \\
\hline & Yuruti: & ba'pú-bisari- & 'companion-?' \\
\hline & Kotiria: & phititia- & 'collective-3’ (?) \\
\hline & Wai'khan & :piti-tia-ro & 'collective-3' (?) \\
\hline
\end{tabular}

As seen in (9), the majority of terms for 'four' in the Western branch languages are relational, but the forms themselves are not cognate (Thiago Chacon, p.c.). Although the Nadahup case discussed above does suggest that inheritance of a metaphorical association, rather than a specific construction or form, is possible, the relational terms in these languages probably owe their existence to calquing (or even, as in the Barasano case, to lexical borrowing): Barasano, Desano, and Siriano are in frequent contact (mostly via intermarriage) with languages of the Eastern branch, whereas contact involving Kubeo, Retuarã, and Makuna (of which the latter two lack relational forms) is much more limited.

For the Eastern branch, a relational 'four' term *bapa-ri does appear to be fully reconstructable. However, the form could also have easily been internally calqued using cognate components, since these languages experience relatively intense contact via the linguistic exogamy system. Unlike Algonquian 'whisky', meaning gives us no additional clues, so a reconstruction of relational 'four' in the Eastern East Tukanoan languages can be assessed as only possible, not probable.

In fact, a wider comparative view indicates that relational 'four' originated beyond East Tukanoan, regardless of whether it spread by contact or inheritance within this family. Relational terms for 'four' (and in some cases for 'three', 'five', or other values) are widespread throughout the Amazon basin; they occur in about $25 \%$ of 195 languages surveyed, distributed across at least thirteen different families/isolates from French Guyana to Peru to Paraguay (see Epps et al., 2012; Epps and Hansen, in prep.); compare, for example, Miraña [Boran] tsane'ná?be'ßahkátsi- 'being companions to each other, 4', Xavánte [Macro-Jê] mro po 'with companion/spouse, 4', etc.

Despite their widespread occurrence across Amazonian language families, relational numeral terms are not generally reconstructable beyond very shallow time-depth. In fact, the only language families in which they occur more than sporadically are Nadahup and East Tukanoan, which as discussed above can probably be attributed (at least in part) to calquing; some Jê and Macro-Jê languages, in which their wide heterogeneity in form, value $(3,4,5)$, and literal meaning (e.g. 'spouse', 'friend', etc.) also indicates that inheritance is 
unlikely; ${ }^{14}$ and languages of the Tupi-Guaraní family. Given the low probability of independent innovation, language contact has almost certainly played a role in the emergence of most of the Amazonian relational numeral terms. This contact undoubtedly involved direct calquing in some instances, but substrate influence and other forms of accommodation may also have been implicated.

The Tupi-Guaraní family presents an intriguing exception to the sporadic attestation of relational 'four' terms within particular Amazonian families. Relational terms are widespread in Tupi-Guarani, making inheritance appear somewhat more plausible. Moreover, if relational 'four' reconstructs, its timedepth and the wide geographic distribution of Tupi-Guaraní languages would point to this family as a plausible source for the diffusion of relational terms into other Amazonian languages. But what evidence do we have that relational 'four' is inherited in Tupi-Guaraní? As shown in Fig. 3 below, relational 'four' terms - most of which are based on the root *iru 'accompany' (reconstructed by Mello, 2000: 163)—are attested in languages throughout the 'Main' TupiGuaraní subgroup, according to the family tree proposed by ChousouPolydouri et al. (in prep; see also the largely comparable subgroupings proposed by Lemle, 1971 and Rodrigues and Cabral, 2002). Mello's reconstruction of Proto-Tupi-Guaraní includes *iruni 'four' (2000: 163), based on the reflexes listed in (11), but in fact these languages belong only to the Guaranían subgroup of Tupi-Guaraní (see Fig. 3), with the exception of Tupinambá (which was spoken along the Brazilian coast, adjacent to Guaranían languages).

(11) Reflexes of Tupi-Guaraní *iruní (relational 'four'; Mello, 2000: 163)

Tupinambá: iruni

Lingua Geral: $\quad$ iruni $^{15}$

Guaraní Mbya: iruni

Paraguayan Guaraní: $\quad$ iruni

Chiriguano: irrunt

Old Guaraní: $\quad$ iruni

Tapiete: $\quad$ urundit (Gonzales, 2005: 126)

${ }^{14}$ Note that partial or imperfect calquing is quite common among the world's languages; compare the well-known examples of 'skyscraper', e.g. German Wolkenkratzer 'cloud-scratcher' vs. French gratte-ciel 'scratch-sky'.

15 Anchieta (1595; see also Eckart (1890 [1753-1757]: 4) gives the form monherondye (probably mô-irundi; see comparable examples listed by Mello 2000:163 for 'accompany' and 'four' across Tupi-Guaraní languages). 
Beyond the Guaranían subgroup of the family, however, relational numeral terms are not regular in form, although most do involve some reflex of *iru 'accompany':

(12) Other Tupi-Guaraní relational 'four' terms ${ }^{16}$

Guayarú: iranantú (Schmidt, 1936)

Kokama: iruaka (Vallejos, 2010: 264)

Omagua: $\quad$ iruaka (Lev Michael p.c.)

Tembé: $\quad$ uzejiru-irupatu (Mello, 2000: 163)

Wayampí: iröte (Olson, 1978: 11)

Kayabí: $\quad$ irupãwẽ (Dobson, 1997: 125)

Kamaiura: mojoiri $\tilde{\boldsymbol{u}}$ (Seki, 2000)

Asurini do Xingu: iroma'e (means 'three'; Nicholson, 1982: 29-30)

Asurini do Tocantins/Trocará: irogatoete (Nicholson, 1978: 28)

Parakanã: i'rogatoète (Silva, 2003: 70)

Tapirapé: täiró (Praça, 2007: 149-151)

(13) Non-relational 'four' terms in Tupi-Guaraní

Ava-Canoeiro: $\quad$ oilopakatu, oikopa'te (Mello, 2000: 163)

Urubu-Ka'apor: tumeme (Kakumasu, 2007: 139)

Apiaká: $\quad$ mukũjjatu ('two-?'; Mello, 2000: 163)

Araweté: $\quad$ kukũũ (Mello, 2000: 163)

Emerillon: momokonte ('two-Focus'; Rose, 2003: 195)

Sirionó: $\quad$ teremō-ha (Mello, 2000: 163)

Xeta: $\quad$ mokäj mokäj ('two two'; Vasconcelos, 2008: 13)

So what is the history of relational 'four' within Tupi-Guaraní? The reconstructed term *iruni was probably inherited in the Guaranían branch, while its occurrence in Tupinambá could plausibly be due to calquing. Elsewhere in the 'Main' branch of Tupi-Guaraní, inheritance is plausible, but would have necessarily involved the metaphorical association between 'four' and 'companion', rather than a fully established form-much as was suggested above for the Nadahup forms for 'two' based on 'eye'. This scenario is favored by Schleicher (1998: 13) in his reconstruction of Proto-Tupi-Guaraní; in noting the variability of the forms across the family, he posits that only the strategy associating 'four' with *iru 'companion' was conventionalized when the protolanguage split up.

The only plausible alternative explanation is that relational 'four' entered the majority of the Tupi-Guaraní languages by calquing, whether directly

${ }^{16}$ Compare also Guajájara zeiruyatú, zerirongatu (Roberts and Symes, 1936: 245; Green, 1997: 5) and Akawere tapisar ('companion'; see Boudin, 1966: 90). 


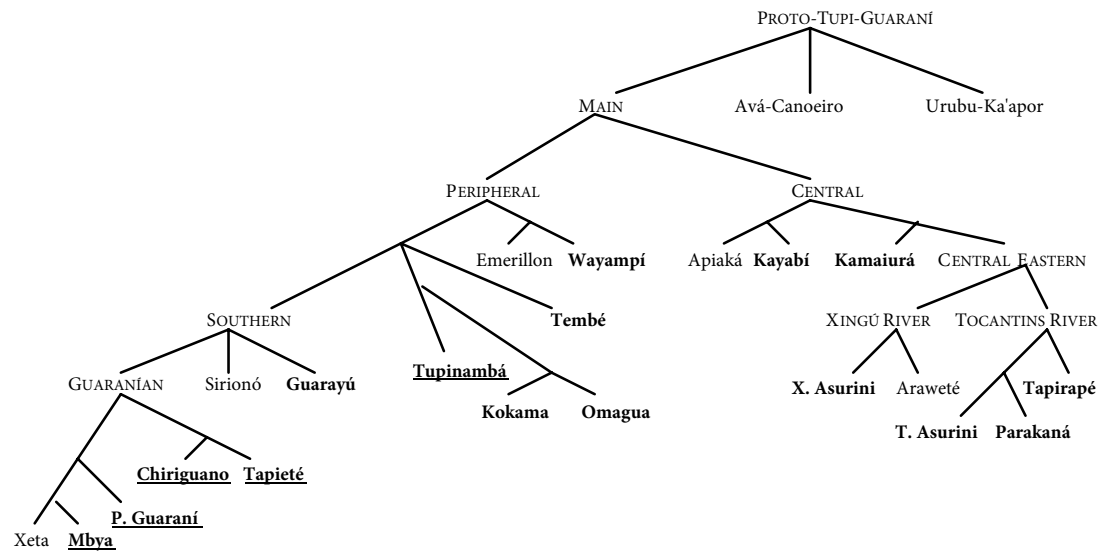

Figure 3. Relational 'four' in Tupi-Guaraní languages.

(bold + underline: reflexes of *iruni; bold: other 'relational' form; plain: 'four' term does not appear to be relational; classification Chousou-Polydouri et al., in prep.)

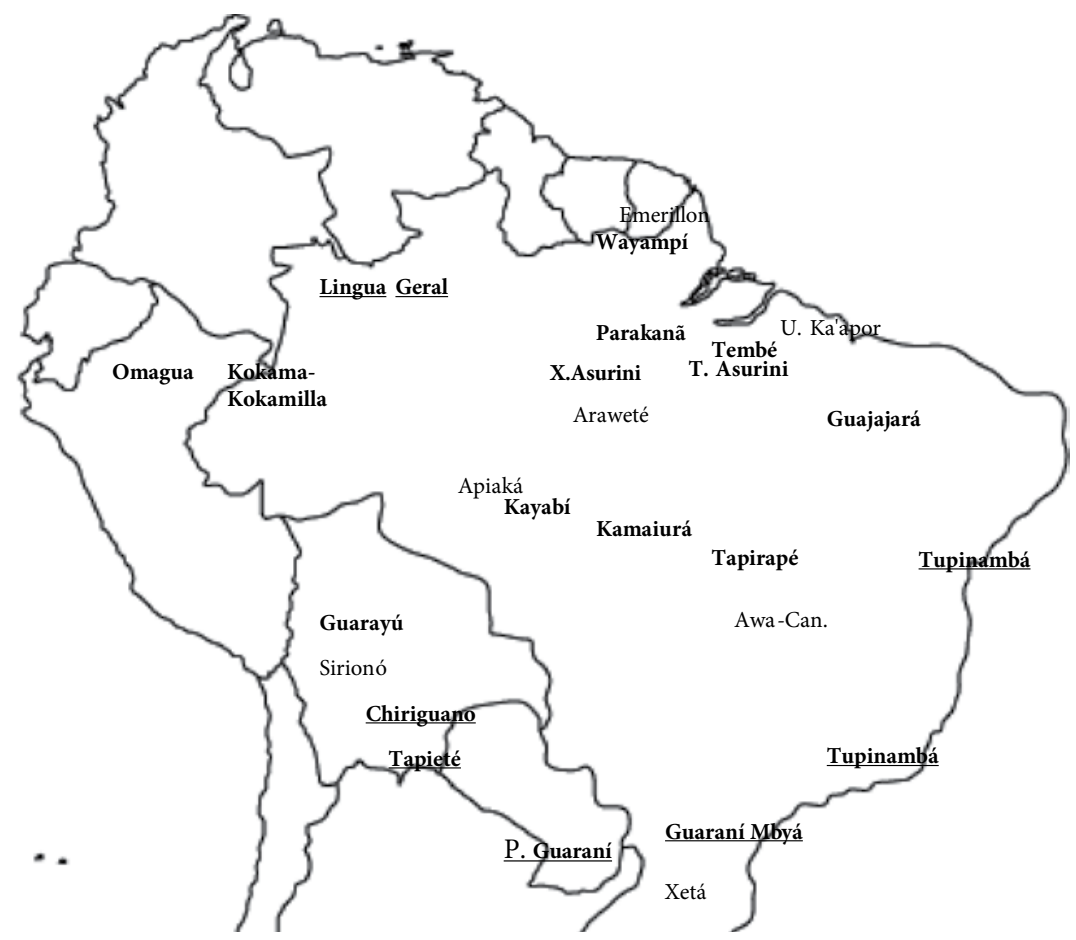

Figure 4. Tupi-Guaraní languages.

(bold + underline: reflexes of *iruni; bold: other 'relational' form) 
from neighboring languages or via substratum influence. However, it is clear that the term cannot be a recent calque within the Tupi-Guaraní family; as Figure 4 illustrates, the languages are widely dispersed, and have probably been so for some 1000-2000 years (Noelli, 2008). While it is possible that relational 'four' entered many of the Tupi-Guaraní languages via localized processes of calquing (e.g. within the Vaupés, the Xingú, and other regions), this scenario gives us no explanation for how relational 'four' became so widely distributed across Amazonia in the first place, especially given its relatively shallow time-depth in the majority of the language families in which it appears. Tupi-Guaraní languages, on the other hand, present a reasonable motor of spread by which the strategy could have been implanted in these farflung regions in the first place, after which it could have been transferred among other local languages. We can probably never know whether the strategy was first innovated within Tupi-Guaraní or was calqued into the family at some upper node of the tree; however, its recurrence among these geographically far-flung languages does suggest that it was inherited through much of the Peripheral and/or Central subgroups.

In sum, comparative, geographical, and typological evidence points to the inheritance of relational 'four' within at least a major branch (Guaranían or higher) of the Tupi-Guaraní family. While the general lack of a comparable form of this morphologically complex numeral term challenges our reconstruction, we can nevertheless assess it as more probable than the possible reconstructions of other complex forms in the region, such as the relational 'four' term in East Tukanoan languages - among which intense, ongoing contact points to family-internal calquing — and 'hand'-based terms for 'five' in other families, which could be due to either calquing or to independent innovation.

\section{Conclusion}

As can be seen in the case of Amazonian numeral terms, complex forms are subject to a variety of historical processes that are of different relevance to simplex lexical items. The Vaupés languages offer ample illustration that complex forms may be readily calqued, even when lexical borrowing is avoidedsuggesting that complex forms are susceptible to different kinds of speaker awareness and manipulation. Complex forms are likewise prone to innovation via strategies like compounding that are not applicable to simplex forms. Furthermore, when complex forms are inherited, the Amazonian evidence suggests that they may follow a trajectory that is much less accessible to 
simplex forms; in particular, a metaphorical association may be more stable than form, and continued salience of the metaphor over time may even restrain full lexicalization.

In light of the distinct historical pathways open to morphologically complex and simplex lexical items, complex forms offer particular challenges to our efforts to determine linguistic history. Where complex forms are attested among related languages, their reconstruction may be very difficult to effect with any degree of certainty_-since corresponding forms may arise through contact-induced change or independent innovation, as well as inheritance, and inheritance itself need not require stability of form. Despite these challenges, however, this paper has argued that not all reconstructions of complex forms are equally hopeless. We do have tools to assess the relative probability of our reconstructions, most notably in typological criteria, which provide information about the likelihood of independent innovation, and geographichistorical criteria, which inform the plausibility of contact-related transfer.

\section{References}

Aikhenvald, Alexandra Y. 1996. Areal diffusion in North-West Amazonia: the case of Tariana. Anthropological Linguistics 38: 73-116.

Aikhenvald, Alexandra Y. 2002a. Dicionário Tariana-Português e Português-Tariana. (Boletim do Museu Goeldi 17: 1.) Museu Goeldi: Belém.

Aikhenvald, Alexandra Y. 2002b. Language Contact in Amazonia. Oxford: Oxford University Press.

Aikhenvald, Alexandra Y. 2003. Multilingualism and ethnic stereotypes: the Tariana of northwest Amazonia. Language in Society 32: 1-21.

Aikhenvald, Alexandra Y. 2007. Grammars in contact: a cross-linguistic perspective. In A.Y. Aikhenvald and Robert M. W. Dixon (eds.), Grammars in Contact: A Cross-Linguistic Typology, 1-66. Oxford: Oxford University Press.

Aikhenvald, Alexandra Y. 2012a. The Languages of the Amazon. Oxford: Oxford University Press.

Aikhenvald, Alexandra Y. 2012b. 'Invisible' loans: how to borrow a bound form. In Lars Johanson and Martine Robbeets (eds.), Copies versus Cognates in Bound Morphology, 167185. (Brill's Studies in Language, Cognition and Culture, 2). Brill, Leiden, The Netherlands.

Anchieta, Joseph de. 1595. Arte da Grammatica da Lingua Mais Usada na Costa do Brasil, Antônio Mariz, Coimbra.

Beier, Christine, Lev Michael, and Joel Sherzer. 2002. Discourse forms and processes in indigenous lowland South America: an areal-typological perspective. Annual Review of Anthropology 31: 121-145.

Bloomfield, Leonard. 1946. Algonquian. In Harry Hoijer (ed.), Linguistic Structures of Native America, 85-129. New York: Viking Fund Publications in Anthropology.

Bolaños, Katherine. 2010. Composiciones verbales en Kakua. Estrategias para codificar movilidad, direccionalidad y secuencia. Paper presented at the Amazonicas 3 conference, Bogotá, Colombia. April 19-24. 
Bolaños, Katherine and Patience Epps. 2009. Linguistic classification of Kakua, a language of northwest Amazonia. Paper presented at the IV Congress on Indigenous Languages of Latin America CILLA, Austin, Texas.

Boudin, Max. 1966. Dicionário de Tupi Moderno (Dialeto Tembé-Ténêtehar do Alto Rio Gurupi). Faculdade de Filosofia, Ciências e Letras de Presidente Prudente.

Bowern, Claire, Patience Epps, Russell Gray, Jane Hill, Keith Hunley, Patrick McConvell, and Jason Zentz. 2012. Does lateral transmission obscure inheritance in hunter-gatherer languages? PLoS ONE 6(9): e25195.

Buchillet, Dominique. 1992. Nobody is there to hear: Desana therapeutic incantations. In E. Jean Matteson Langdon and Gerhard Baer (eds.), Portals of Power: Shamanism in South America, 211-230. Albuquerque: University of New Mexico Press.

Campbell, Lyle. 1997. American Indian Languages. New York: Oxford University Press.

Campbell, Lyle, Terrence Kaufmann, and Thomas Smith-Stark. 1986. Mesoamerica as a linguistic area. Language 62: 530-70.

Carlin, Eithne. 2006. Feeling the need: The borrowing of Cariban functional categories into Mawayana (Arawak). In Alexandra Y. Aikhenvald and Robert M.W. Dixon (eds.), Grammars in Contact: A Cross-Linguistic Perspective, 313-332. (Explorations in Linguistic Typology, Vol. 4.) Oxford: Oxford University Press.

Chacon, Thiago. Forthcoming. A revised proposal of Proto-Tukanoan consonants and Tukanoan family classification. International Journal of American Linguistics.

Chousou-Polydouri, Natalia, Vivian Wauters, Zachary O'Hagan, Keith Bartolomei, and Lev Michael. In prep. A Bayesian phylogenetic internal classification of the Tupí-Guaraní family. Ms.

Dixon, Robert M.W. and Alexandra Aikhenvald. 1999. Introduction. In Robert M. W. Dixon and Alexandra Aikhenvald (eds.), The Amazonian Languages, 1-22. Cambridge: Cambridge University Press.

Dobson, Rose. 1973. Notas sobre os substantivos do Kayabí, Série Lingüistica 1: 30-56. Brasília: Summer Institute of Linguistics.

Eckart, Anselm. 1890 (1753-1757). Specimen Linguae Brasilicae Vulgaris, ed. by Julius Platzmann. Leipzig.

Epps, Patience. 2006. Growing a numeral system: the historical development of numerals in an Amazonian language family. Diachronica 23: 259-288.

Epps, Patience. 2007. The Vaupés melting pot: Tukanoan influence on Hup. In Alexandra Aikhenvald and Robert M. W. Dixon (eds.), Grammars in Contact: A Cross-Linguistic Typology, 267-289. (Explorations in Linguistic Typology 4.) Oxford: Oxford University Press.

Epps, Patience. 2008a. Grammatical borrowing in Hup. In Yaron Matras and Jeanette Sakel (eds.), Grammatical Borrowing: A Cross-Linguistic Survey, 551-566. Berlin: Mouton de Gruyter.

Epps, Patience. 2008b. A Grammar of Hup. Berlin: Mouton de Gruyter.

Epps, Patience. 2009a. Language classification, language contact, and Amazonian prehistory. Language and Linguistics Compass 3(2): 581-606.

Epps, Patience. 2009b. Loanwords in Hup, a Nadahup language of Amazonia. In Martin Haspelmath and Uri Tadmor (eds.), Loanwords in the World's Languages: A Comparative Handbook, 993-1014. Berlin and New York: De Gruyter Mouton.

Epps, Patience. 2012. Ideology and perspective: considering sociocultural correlates of Amazonian linguistic diversity. Paper presented at the conference Patterns of Diversification and Contact: A Global Perspective. Royal Netherlands Academy of Arts and Sciences (KNAW), Amsterdam, Dec. 13. 
Epps, Patience. Forthcoming. Language and subsistence patterns in the Amazonian Vaupés. In Tom Güldemann, Richard Rhodes, and Patrick McConvell (eds.), The Languages of HunterGatherers: Global and Historical Perspectives. Cambridge: Cambridge University Press.

Epps, Patience, Claire Bowern, Cynthia Hansen, Jane Hill, and Jason Zentz. 2012. On numeral complexity in hunter-gatherer languages. Linguistic Typology 16: 39-107.

Epps, Patience and Cynthia Hansen. In prep. One, two, three, brother: numeral etymologies and language contact in Amazonia. Ms.

Epps, Patience and Kristine Stenzel. 2013. Introduction: cultural and linguistic interaction in the Upper Rio Negro region. In Patience Epps and Kristine Stenzel (eds.), Upper Rio Negro: Cultural and Linguistic Interaction in Northwestern Amazonia. Rio de Janeiro: Museu do Índio-FUNAI.

Fausto, Carlos, Bruna Franchetto and Michael J. Heckenberger. 2008. Language, ritual and historical reconstruction: towards a linguistic, ethnographical and archaeological account of Upper Xingu Society. In David K. Harrison, David S. Rood and Aryenne Dwyer (eds), Lessons from Documented Endangered Languages, 129-158. (Typological Studies in Language 78.) Amsterdam: John Benjamins Publishing Company.

Floyd, Simeon. 2013. Semantic transparency and cultural calquing in the northwest Amazon. In Patience Epps and Kristine Stenzel (eds.), Upper Rio Negro: Cultural and Linguistic Interaction in Northwestern Amazonia. Rio de Janeiro: Museu do Índio-FUNAI.

Gomez-Imbert, Elsa. 1996. When animals become 'rounded' and 'feminine': conceptual categories and linguistic classification in a multilingual setting. In John Gumperz and Stephen Levinson (eds.), Rethinking Linguistic Relativity, 438-469. Cambridge: Cambridge University Press.

Gomez-Imbert, Elsa. 2009. O número quatro e seus 'companheiros'. Etnolingüística listserv, http://lista.etnolinguistica.org/1905.

Gonzales, Hebe Alicia. 2005. A grammar of Tapiete (Tupi-Guaraní). Ph.D dissertation, University of Pittsburgh.

Green, Diana. 1997. Diferenças entre termos numéricos em algumas línguas indígenas do brasil. Boletim do Museu Paraense Emilio Goeldi, Série Antropologia 13: 179-207.

Hill, Jonathan D. 1988. The soft and the stiff: ritual power and mythic meaning in a northern Arawak classifier system. Anthropologica 69: 55-77.

Hill, Jonathan D. 2009. Made from Bone. Trickster Myths, Music and History from the Amazon. Chicago: University of Illinois Press.

Hock, Hans Heinrich. 1991. Principles of Historical Linguistics. Berlin: Mouton de Gruyter.

Hockett, Charles F. 1948. Implications of Bloomfield's Algonquian studies. Language 24: 117-131.

Huber, Randall and Robert Reed. 1992. Comparative Vocabulary: Selected Words in Indigenous Languages of Colombia. Bogotá: SIL.

Jackson, Jean. 1983. The Fish People: Linguistic Exogamy and Tukanoan Identity in Northwest Amazonia. Cambridge: Cambridge University Press.

KakumasuJames Y. and Kiyoko Kakumasu. 2007. Dicionário por Tópicos Kaapor-Português. Cuiabá: SIL Brasil.

Kay, Paul, and Luisa Maffi. 1999. Color appearance and the emergence and evolution of basic color lexicons. American Anthropologist 101(4): 743-760.

Lemle, Miriam. 1971. Internal classification of the Tupí-Guaraní linguistic family. In D. BendorSamuel (ed.), Tupi Studies I, Summer Institute of Linguistics Publications in Linguistics and Related Fields, 107-129. Summer Institute of Linguistics (SIL).

Levinson, Stephen. 2001. Yèlî Dnye and the theory of basic color terms. Journal of Linguistic Anthropology 10(1): 3-55. 
Lyons, Sir John. 1999. The vocabulary of colour with particular reference to ancient Greek and Classical Latin. In Alexander Borg (ed.), The Language of Color in the Mediterranean: An Anthology on Linguistic and Ethnographic Aspects of Color Terms, 38-75. Stockholm: Almqvist and Wiksell.

Martins, Silvana. 2004. Fonologia e gramática Dâw. Ph.D dissertation, LOT publications. Amsterdam: Vrije Universiteit.

Martins, Silvana A. and Valteir Martins. 1999. Makú. In R. M. W. Dixon and Alexandra Aikhenvald (eds.), The Amazonian Languages, 251-268. Cambridge: Cambridge University Press.

Martins, Valteir. 1994. Análise prosódica da língua Dâw (Makú-Kamã) numa perspectiva nãolinear. MA thesis, Universidade Federal de Santa Catarina.

Mello, Antônio Augusto Souza. 2000. Estudo histórico da familia linguistica Tupi-Guaraní. $\mathrm{Ph} . \mathrm{D}$ dissertation, Universidade Federal de Santa Catarina.

Miller, Marion M. 1999. Desano Grammar. Dallas: Summer Institute of Linguistics.

Morse, Nancy L. and Michael B. Maxwell. 1999. Cubeo Grammar. Dallas: Summer Institute of Linguistics.

Neves, Eduardo G. 2001. Indigenous historical trajectories in the Upper Rio Negro Basin. In Colin McEwan, Cristiana Barreto, and Eduardo G. Neves (eds.), Unknown Amazon: Culture and Nature in Ancient Brazil, 266-286. London: British Museum Press.

Nicholson, Velda. 1978. Aspectos da Lingua Assurini. Brasília: Summer Institute of Linguistics.

Nicholson, Velda. 1982. Breve Estudo da Lingua Asurini do Xingu. (Ensaios Lingüísticos, 5.) Brasília: Summer Institute of Linguistics.

Noelli, Francisco Silva. 2008. The Tupí expansion. In Helaine Silverman and William Isbell (eds.), Handbook of South American Archeology, 659-670. New York: Springer.

Olson, Roberta. 1978. Dicionário por Tópicos nas Linguas Oiampí (Wajampi-Português), (Ensaios Lingüísticos 2.) Brasília: Summer Institute of Linguistics.

Ospina Bozzi, Ana Maria. 2002. Les structures élémentaires du Yuhup Makú, langue de l'Amazonie Colombienne: morphologie et syntaxe. Thèse de doctorat, Université Paris 7 Denis Diderot.

Praça, Walkíria Neiva. 2007. Morfossintaxe da língua Tapirapé. Ph.D dissertation, Universidade de Brasília.

Ramirez, Henri. 1997. A Fala Tukano dos Yépa-Masa, Vol. 2: Dicionario. Manaus: Inspetoria Salesiana Missionária da Amazônia, CEDEM.

Ramirez, Henri. 2001. Dicionário da Lingua Baniwa. Manaus: Editora da Universidade do Amazonas.

Roberts, F. J. and S. P. Symes. 1936. Vocabulary of the Guajajara dialect. Journal de la Société des Américanistes 28: 209-248.

Rodrigues, Aryon. 2000. Panorama das línguas indígenas da Amazônia. In Francesc Queixalós and Odile Renault-Lescure (eds.), As Linguas Amazônicas Hoje, 15-28. São Paulo: Instituto Socioambiental, Museu Parense Emílio Goeldi.

Rodrigues, A. D. and A. S. A. C. Cabral. 2002. Revendo a classificação interna da família tupíguaraní. In A. S. A. C. Cabral and A. D. Rodrigues (eds.), Linguas Indigenas Brasileiras: Fonologia, Gramática e História, 327-337. Belém: Editora Universitária, Universidade Federal do Pará.

Rose, Françoise. 2003. Morphosyntaxe de l'émerillon. Thèse de doctorat, Université Lumière Lyon 2.

Sapir, Edward. 1921. Language. New York: Harcourt and Brace.

Schleicher, Charles. 1998. Comparative and internal reconstruction of the Tupí-Guaraní language family. Ph.D dissertation, University of Wisconsin. 
Schmidt, Max. 1936. Vocabulario de la lengua Guarayu. Revista de la Sociedad Científica del Paraguay 3: 176-187.

Seifart, Frank. 2011. Bora Loans in Resigaro: Massive Morphological and Little Lexical Borrowing in a Moribund Arawakan Language. Cadernos de Etnolinguistica, Série Monografias 2.

Seki, Lucy. 2000 Gramatica do Kamaiura: Lingua Tupi-Guarani do Alto Xingu. São Paulo: Editora UNICAMP and São Paulo State Official Press.

Seki, Lucy. 2011. Alto Xingu: uma sociedade multilíngue? In Bruna Franchetto (ed.), Alto Xingu: Uma Sociedade Multilingue, 57-86. Rio de Janeiro: Museu do Indio-FUNAI.

Silva, Gino Ferreira da. 2003. Construindo um dicionário parakaná-português. MA thesis, Universidade de Pará, Belém.

Silverstein, Michael. 1981. The limits of awareness. Working Papers in Sociolinguistics no. 84. Austin, Texas: Southwest Educational Development Laboratory.

Stenzel, Kristine S. 2004. A reference grammar of Wanano. Ph.D dissertation, University of Colorado.

Stenzel, Kristine. 2005. Multilingualism in the Northwest Amazon, revisited. Memorias del Congreso de Idiomas Indígenas de Latinoamérica-II, University of Texas at Austin.

Stenzel, Kristine S. Forthcoming. Contact and innovation in Vaupés possession-marking strategies. In Patience Epps and Kristine Stenzel (eds.), Upper Rio Negro: Cultural and Linguistic Interaction in Northwestern Amazonia. Rio de Janeiro: Museu do Índio-FUNAI.

Stenzel, Kristine and Elsa Gomez-Imbert. 2009. Contato linguístico e mudança linguística no noroeste amazônico: o caso do Kotiria (Wanano). Revista da ABRALIN 8: 71-100.

Strom, Clay. 1992. Retuarã Syntax. (Studies in the languages of Colombia 3.) Dallas: Summer Institute of Linguistics.

Vallejos, Rosa. 2010. A grammar of Kokama-Kokamilla. Ph.D dissertation, University of Oregon.

Vasconcelos, Eduardo Alves. 2008. Aspectos fonológicos da língua Xetá. MA thesis, Universidade de Brasilia.

Weir, E. M. Helen. 1984. A negação e outros tópicos da gramática Nadëb. MA thesis Universidade de Campinas. 